\title{
Expectations on Track? High School Tracking and Adolescent Educational Expectations
}

Karlson, Kristian Bernt

Published in:

Social Forces

DOI:

$10.1093 /$ sf/sov006

Publication date:

2015

Document version

Early version, also known as pre-print

Citation for published version (APA):

Karlson, K. B. (2015). Expectations on Track? High School Tracking and Adolescent Educational Expectations.

Social Forces, 94(1), 115-141. https://doi.org/10.1093/sf/sov006 


\title{
Expectations on Track? \\ High School Tracking and Adolescent Educational Expectations
}

\author{
Author: Kristian Bernt Karlson (kbk@soc.ku.dk)
}

THIS PAPER IS PUBLISHED IN

SOCIAL FORCES 2015

Online pre-print version

Access paper here:

http://sf.oxfordjournals.org/content/early/2015/02/04/sf.sov006

\section{Please notice: According to SHERPA/ROMEO, this paper cannot be archived in the university database. Please access the paper via the link to the publisher provided above.}

\begin{abstract}
This paper examines the role of adaptation in expectation formation processes by analyzing how educational tracking in high schools affects adolescents' educational expectations. I argue that adolescents view track placement as a signal about their academic abilities and respond to it in terms of modifying their educational expectations. Applying a difference-in-differences approach to the National Educational Longitudinal Study of 1988, I find that being placed in an advanced or honors class in high school positively affects adolescents' expectations, particularly if placement is consistent across subjects and if placement contradicts tracking experiences in middle school. My findings support the hypothesis that adolescents adapt their educational expectations to ability signals sent by schools.
\end{abstract}

